\title{
I Want to Know More About You: On Knowing and Acknowledging in Chinatown
}

\author{
Francey Russell
}

Throughout his writings Stanley Cavell brings our attention to the difference between knowing and acknowledging, and has urges philosophers to recognize that the skeptical, epistemic problem of other minds might actually be part of an effort to avoid the ordinary, ethical difficulties of acknowledgment. What makes the latter so challenging to understand is Cavell's suggestion that acknowledgment cannot be elucidated via definition or conceptual analysis; instead, we can come to appreciate what acknowledgment means by learning to recognize instances of its success and cases of its failure, both in life and in art.

An exemplary case study of the problems of knowing and acknowledging would involve an exploration of both the temptation to treat another human being as an object to be known-figured out and laid bare-and an effort to grapple with the human need to acknowledge and be acknowledged. Such a case study would illustrate how the effort to know a person can obscure the ethical underpinnings, and how concrete opportunities for acknowledgment can be missed or seen too late, illustrating not only the

F. Russell ( $\square)$

Yale University, New Haven, CT, USA

(C) The Author(s) 2018

G. L. Hagberg (ed.), Stanley Cavell on Aesthetic Understanding,

Philosophers in Depth, https://doi.org/10.1007/978-3-319-97466-8_1 
difficulty of recognizing the need for acknowledgment generally speaking, but the difficulty of realizing that this gesture or this comment or this silence constituted an expression of that need. It would have to show, as Cavell repeatedly emphasizes, the costs of knowing and acknowledging, a cost that Cavell sees philosophy as tending to forget. My proposal in this chapter is that we can find such an exemplary case study in Roman Polanski's Chinatown ${ }^{1}$ and in the genre of film noir more generally. The genre and this instance afford us a kind of aesthetic understanding which, since acknowledgment is the issue, also constitutes a kind of self-understanding.

A descendent or perversion of the detective genre (see Durgnat 1998), film noir takes as part of its basic thematic motivation the problem or pursuit of knowledge (see "Towards a Definition of Film Noir" in Borde and

\footnotetext{
${ }^{1}$ What are the ethics of turning to a film by Roman Polanski as part of an exploration of the dynamics of acknowledgment? What are the ethics of turning to his films at all anymore, after everything we know? Speaking for myself, this difficulty is compounded in that not only do I think that Chinatown is one of the greatest films ever made, I also think Polanski has made a number of important films about women and their protest against the world: in addition to Chinatown, there is Repulsion (1965), Rosemary's Baby (1968), Tess (1979), even The Tenant (1976). But of course, thinking about these films, it is impossible not to think of the women in Polanski's life, most significantly Samantha Gailey, whom Polanski was charged with raping at Jack Nicholson's house while she was 13 years old, and in more recent years: Charlotte Lewis, a woman identified as Robin M., Renate Langer, and Marianne Barnard. How on earth do we reconcile what this man has done or been accused of doing to women, with an appreciation of his films, let alone the idea that some of his films make interesting, important claims about women's lives? Some might justifiably take Polanski's actions as more than enough reason to give up on his movies, certainly ground enough to give up any expectation that his films could display sensitivity to women's lives. I myself do not know how our thinking about his movies should be informed by our knowledge of the facts of Polanski's life, what he did or what he suffered (his mother, Bula, was murdered while pregnant in Birkenau; his wife, Sharon Tate, was murdered while pregnant by the Manson family). For me this remains an ever open, always troubling question. I do not think it is strictly fallacious to understand a work in light of the artist's life (the idea that it is is known as the "biographical fallacy"; see also "The Death of the Author"); I also do not feel prepared to reject works of art once I've learned that their creators were awful. These issues raise properly philosophical questions about the role that an artist's character should play in thinking about his or her art (a question that takes unique form when it comes to a collaborative medium like film). For now I believe it is possible to engage critically with movies made by Polanski while avoiding the cult-of-(male)-genius and without ignoring what he did. For further discussion of this problem, see Dederer (2017) and the Daily Nous roundtable discussion "Philosophers on the Art of Morally Troubling Artists" (2017).
} 
Chaumeton 2002). The hero, or anti-hero, is usually in the business of knowing and discovering-for example, a private eye (the majority of noirs, including The Big Sleep, Out of the Past, and Kiss Me Deadly), a police officer (Touch of Evil), a journalist (Ace in the Hole), and so on-and the plot hinges on his being plunged into a disorientated state of not knowing. Unlike Sherlock Holmes whose neutrality and isolation ${ }^{2}$ allow him to solve mysteries brought to him by and of concern to others, the noir hero is himself implicated in the mystery he is meant to solve; the pursuit of knowledge becomes a matter of not just professional but personal significance, the success or failure of which has consequences for who he takes himself to be and the world he takes himself to inhabit.

Noir presents a world in which our confidence in human knowledge and knowing is tested under the pressure of certain difficult "realities"; 3 not only the reality of human corruptibility and the implications of war (noir is often understood as a uniquely "post-war" phenomenon), but even more intimately and philosophically, noir grapples with the reality of human separateness, the difficulty of knowing an other, and the possibility that in the realm of human relationships knowing, conceived as a matter of gathering information (the detective's or PI's modus operandi), will neither suffice nor satisfy. Following Cavell, we might say that the dissatisfactions of knowledge would be supplemented by acknowledgment, but that such human responsiveness to one another is rarely achieved in the world of noir-which is to say that noir evidences acknowledgment and the need for it primarily through its failure.

The archetypal characters of noir are representatives of human knowing, types recognizable for their particular epistemic postures. The decent detective, as one example, is a knowledge seeker whose moral uprightness is expressed in his commitment to discovering the truth (The Big Heat, Laura); in cases where the detective is corrupt, his corruption or moral failure lies not just in his violent crimes but in his efforts to distort or conceal some truth (L.A. Confidential). One's relationship with truth and knowledge, then, has implications for one's ethical orientation and

\footnotetext{
${ }^{2}$ In "The Hound of the Baskervilles," for example, Holmes tells Watson: "it is a singular thing, but I find that a concentrated atmosphere helps a concentration of thought. I have not pushed it to the length of getting into a box to think, but that is the logical outcome of my convictions." Holmes radically isolates himself in order to think, a posture and possibility which is unthinkable in noir.

${ }^{3}$ Cora Diamond discusses the idea of the "difficulty of reality" as a challenge to traditional moral philosophy in her essay "The Difficulty of Reality and the Difficulty of Philosophy," Partial Answers: Journal of Literature and the History of Ideas 1, no. 2 (2003).
} 
capacities. The private eye is presented as especially morally ambiguous precisely because his business consists in selling the truth, making a profit off of knowledge, and in so doing disrespecting our faith that truth and knowledge rest rightly outside the realm of capital (The Maltese Falcon, Chinatown). ${ }^{4}$

With respect to the general plots of noirs, even after truth has been revealed or a case has been cracked, the morally unstable universe that we are left to live in is a world in which we no longer believe that truth is tethered to the good. In noir, the revelation of truth, when and if it comes, rarely provides redemption; we might say that in this world truth has lost its appeal or efficacy, or that we have been shaken from our fantasy of its power. Even in instances where a relatively good or upstanding character finally ascends to a position of power (The Big Heat, L.A. Confidential), or love wins out (Gilda), the question we are left with is whether moral principles or a love of truth are still meaningful or efficacious (rather than naïve, wilfully blind, risky, or impotent) in the world of film noir.

Finally, of the highly general claims we can make of the genre, the standard economy of imagery in noir involves a play of space and light that creates an atmosphere of inescapable duplicity and disorientation: dark back alleys, noisy clubs, claustrophobic interiors, blinding police lights, shadows dissecting faces, photographs and mirrors, repetitions and doublings. The city becomes a prison, safe and dangerous spaces become indistinguishable, and the human form-primarily the face-is darkened or obscured, compromising our familiarity and confidence as its disfigurement, whether by shadow or more literally, through violent action, intimates a fearsome unknowability. ${ }^{5}$

Of course, critics like Paul Schrader and Raymond Durgnat have suggested that film noir is best conceived not as a genre at all but as a tone that a film can take, a tone that dominated a certain period in the history of

\footnotetext{
${ }^{4}$ Of course, Sherlock Holmes also sells his knowledge. But the private eye sells private knowledge for private gain - often husbands and wives wanting information on one another, individuals seeking some sort of treasure - and he often has a tarnished history in a more legitimate form of sleuthing or policing; this presents him as morally suspect in a way that Sherlock Holmes is not. Additionally, while Holmes is everywhere showered with praise, noir private eyes are met with derision, skepticism, fear, even laughter.

${ }^{5}$ Consider in The Big Heat Gloria Grahame's face is horribly burnt right as Glenn Ford and we discover that we had misjudged her, wrongly taken her as a double-crosser. She is presented as who she really is, then, only by way of grotesque disfigurement.
} 
American filmmaking and that finds its most apt expression in dark imagery and dark plots. As Schrader (2003) writes, "since film noir is defined by tone rather than genre, it is almost impossible to argue one critic's descriptive definition against another's. How many noir elements does it take to make a film noir noir?" (230). That is, since any list of marks or features common to noirs would be ultimately arbitrary, the task of grouping these films under a commonly defined genre becomes impossible.

In fact, Schrader's approach to noir is not out of step with Cavell's reworked conception of genre. Cavell suggests that we should imagine a genre not as a set of elements common to a class, but more like "a medium in the visual arts, or a 'form' in music" $(1984,28)$. He writes:

the idea is that the members of a genre share the inheritance of certain conditions, procedures and subjects and goals of composition...each member of such a genre represents a study of these conditions, something I think of as bearing the responsibility of the inheritance (ibid.)

For both Schrader and Cavell, then, "film noir" should identify a sustained study of tone, cinematic procedure, goals of composition, andperhaps against Schrader-the exercise of certain critical questions concerning the reach and limits of human knowledge and morality. Film noir offers, we might say, not the repetition of a fixed set of plots but a distinctive way of posing certain questions or, as Schrader puts it, a tone of inquiry.

Both Cavell's and Schrader's approaches attend closely to the fact of generic or tonal development, the fact that the tenor or pitch of noir changes over time, responding both to internal and external conditions, engaging in a kind of cinematic self-reflection that transforms the very thing it seeks to make reflectively explicit. This is not to suggest that what was once noir, imagined as something complete or determinate, eventually becomes something else. Rather, noir would always represent one tone in concert with others, never fully extricable from the full and diverse expression of which it is a part. Thus any transformation in noir is not peripheral or external to the genre but instead newly constitutes that very genre or tone.

One distinctive variation on noir, of which we can regard Chinatown (1975) as an instance, puts a specific emphasis on what can and cannot (or should not) be known, suggesting that the cinema's obsession with turning its gaze on every intimacy or perversity of human life results not in 
ever more knowledge, but in its undoing. In staging an almost Oedipal quest to know at any cost, these films unfold the implications of a perversity or secrecy at the heart of individuals or society; the perverse core of the family, for instance, or the corruption that animates authority. The suggestion, delivered in tone or style as much as plotting, is that the desire to know is too often a desire to know too much, a desire as excessive and perverse as the secret to be revealed. Thus this variant takes noir's abiding concern with the dark and hidden side of the human - and with the audience's desire to encounter it-and renders it horrifically explicit. This is a kind of uncanny noir, a noir concerned with the desire to bring to light, or to screen, what ought to remain hidden. Examples of uncanny noir include, for instance, Welles' The Trial, Aldrich's Kiss Me Deadly, Hitchcock's Vertigo, Lynch's Blue Velvet and Mulholland Drive, Fincher's Se7en, and Polanski's Chinatown.

In Chinatown the impulse to know that finds expression in so much of noir meets its resounding, terrifying, and ultimately tragic limits. The conceptual and ethical need for acknowledgment, as Cavell articulates it, is felt just at the place where the capacity for knowledge is outstripped in the face of another person, and the need for a form of relating other than knowing becomes pronounced. What would it mean for Jake to know Evelyn, and how is this different than knowing what she knows? What would be gained by learning her secret? The film suggests that, in fact, very little is gained by this new knowledge. Instead something is lost: the possibility for something like acknowledgment.

Chinatown, I want to suggest, really involves two films, two ways of seeing or two worlds. The preoccupation with or privileging of the first film drives the plot, head-on and violently, into the second; and in our attempt to attend to and keep pace with the first film, we everywhere miss the signs of the second. As I will try to show, the first film concerns questions of knowledge, the second the possibility of acknowledgment; and, in our fixation on the promise of knowledge, we, along with the protagonist, miss the opportunity for acknowledgment. Hence its tragic ending.

Chinatown's plot, based in part on the California Water Wars, is notoriously complicated and almost impossible to follow on a first viewing; "it is maybe the last of the great complicated story lines that movies dared" (Thompson 1994, 754). I have included a summary in the Appendix, but 
I will offer this plot capsule here: in Chinatown a private detective is caught up in a scandal the reach of which he never fully comprehends; in his attempt to clear his own name, he encounters pervasive and profound corruption, at both public and private levels. This private investigator (PI), Jake Gittes (Jack Nicholson), believes that Evelyn Mulwray (Faye Dunaway) is holding information that could help him solve the mysteries of who set him up; of Water and Power's secret plot; of the role of her father, Noah Cross (John Huston); and of the murder of Evelyn's husband, the chief engineer of Water and Power, Hollis Mulwray. The film's plot consists largely in tracking Jake's efforts to understand these relations, the results of which fail to provide the kind of epistemic satisfaction he'd sought (which means here that the audience too is unsatisfied). That is, in classic noir fashion, the revelation of truth neither fully dissolves the mysteries nor provides anybody's salvation. Instead we find that Jake's pursuit of truth is undermined when brought to bear on the nature of the corruption he was convinced he could understand, even defeat.

In fact the viewer's experience of struggling to follow the plot, of feeling that unless one knows what is going on, one will miss what's important about the film, represents a conviction and commitment to a certain form of understanding that parallels the protagonist's own trajectory. When, in the film's famous last line, his partner tells Jake to "forget it...it's Chinatown," he seems to suggest that even the best collection of knowledge, even the most careful attention to detail, could neither prepare for nor prevent this particular turn of events: total loss is inevitable here, very little can be redeemed. Since some of these characters have worked this beat before and seen things turn similarly sour, the suggestion seems to be that there is nothing to gain from trying to imagine what could have been done differently, nothing to learn. The advice from one detective to another is that to live with Chinatown, it must be forgotten.

So what is "Chinatown"?

What is it about this series of events that accounts for Jake's apparent devastation? Is it just especially sad that a woman with a tragic history should meet a tragic death? Why, in response to a man evidencing such lifelessness, such a terrifying absence of response, would one advise him to just "forget it"? Does Jake know something that is best forgotten? Does Jake now, looking at Evelyn's corpse, know something he did not know before, has this tragedy taught him anything?

I will suggest that Jake's devastation is precisely not a response to new knowledge; rather, if Jake has learned anything (and this remains an open 
question), his devastation at Evelyn's killing is a registration of the thought that in his pursuit of knowledge, he failed to see or hear Evelyn at all, he failed to acknowledge her. "Chinatown" signifies not only, say, the fatedness of human life, the inevitability of corruption, the triumph of the criminal, or the ultimate inconsequence of certain human lives and deaths; rather "Chinatown" can be also understood to signify that a myopic preoccupation with certain kinds of knowledge can obscure solicitation for acknowledgment, and that when the latter goes unmet, there is a real human cost.

In The Claim of Reason (1999), Cavell discusses a presupposition of ordinary language philosophy, namely that our desire to know, and our skepticism about the reliability of our knowledge, must be justified by the concrete context in which this desire emerges; that is, there must be good reason why I would want to know something, and why I would question the reliability of my knowing (see "Austin and Examples," 1999). This represents, Cavell suggests, Austin's attempt to localize and contain skepticism, such that it cannot be loosed on knowledge überhaupt. The idea is that when generalized beyond the particular circumstance that inspired a skeptical attitude, that attitude loses its sense, hence its threatening force. ${ }^{6}$

With respect to Chinatown, this would mean that Jake's suspicious desire to know more about, say, Water and Power, and his conviction that his usual methods for acquiring such knowledge (relying on the testimony of employees, for example) are not trustworthy, must be reasonably justified by those circumstances. And indeed he does have good reason to be suspicious: not only was he set up, but the circumstances surrounding the setup are peculiar: the night time water dumping, Mulwray's mysterious trips to the riverbed, the implausible story about Water and Power benevolently irrigating the farmlands. The problem is that Jake assumes that the reasonableness of his suspicion in this case can extend to every circumstance in which he seeks knowledge; and, as I will claim, in the case of Evelyn, his desire for knowledge (to know what Evelyn knows), and his suspicion of the source of that knowledge (what

\footnotetext{
${ }^{6}$ Cavell of course believed that skepticism can be loosed on knowledge as such, but he follows Austin in suggesting that some actual and "local" experience, encounter, or feeling motivates skepticism about knowledge "generally." That is, whereas Austin believes that the skepticism about knowledge or the world as such is incoherent, Cavell wants to take seriously the thought that the philosopher may have "a special reason, anyway a good enough reason, for raising the question of reality [or knowledge]" $(1982,59)$.
} 
Evelyn says), Jake's skeptical posture is inappropriate. Or rather, Jake's mistake is to take Evelyn to be a problem of knowledge, he believes that some piece of knowledge or information could allay his skepticism, and so he fails to recognize that, to use Cavell's words, our "relation to the world as such is not that of knowing, anyway not what we think of as knowing" (1999, 241).

Another way of putting this is that Jake wants to bring his professional detective's attitude, which is to say a skeptical attitude, to bear on all of his encounters. Three features of Jake's attitude are worth noting. First, his method is invasive yet detached; he follows individuals without their knowledge, he photographs them in private moments of which he is not a part, his métier as a PI is "matrimonial work," which is to say he specializes in observing the workings of marriages without being himself involved in an intimate relationship. Second, Jake is suspicious by habit and by trade, ready to regard any apparently ordinary situation as suspect. It is this general posture that allows him to perceive the mysteriousness of a drunk who drowned in a dry riverbed or to assume that the deputy chief of Water and Power is lying when he claims that his department is irrigating farmland out of pure goodwill. Finally, Jake takes himself to be an expert in matters of observation and acquiring evidence, much of which involves being skilled at reading other human beings. His work as a PI has taught him (he thinks) much about marriages, about relationships, about individuals and what they hide from one another, and about what it means to discover such hidden things. His confidence in his own expertise, then, allows him to imagine what someone might be hiding or lying about. Insofar as he thinks that his relation to the world is fundamentally a suspicious yet authoritative relation of knowing, we might say that, crucially and fatally, Jake thinks he knows what it is he doesn't know. If he accuses someone of hiding something, it is because he already has a sense of what that thing might be.

Jake's general attitude is well displayed in his first private meeting with Evelyn Mulwray. He arranges to meet with her after his nose has been cut following his snooping into the dealings of Water and Power, and after her husband has been found drowned. Jake, nose bandaged, meets Evelyn, veiled, in a dark bar; significantly, in this intimate meeting, both faces are obscured.

Jake tells Evelyn that what she's told him so far “isn't good enough...I think you short-changed me on the story. Something besides the death of your husband was bothering you." In so saying, Jake suggests first, that he 
can tell she is lying and has an idea of the kind of thing she is concealing; second, he suggests that he was able to make this adept conclusion based on what he takes to be an unconvincing expression of grief. "You were upset," he says, "but not that upset." Evelyn responds, "Mr. Gittes, don't tell me how I feel."

Pressing her-“I think you're hiding something"-Evelyn confesses that she hasn't been fully honest. She tells Jake that she knew about her husband's affair and that, far from being upset, she was "grateful." To this Jake responds, "look, I do matrimonial work, it's my métier. When a wife tells me that she was relieved her husband was cheating on her, it runs contrary to my experience," implying here, as he does in his accusation, that she did not display sufficient feeling, that he knows best what it means to grieve a husband and what it means to discover infidelity. When Evelyn tells him that she too was cheating-or rather, she does not disconfirm Jake's assumption-he asks still more questions, until she finally tells him, "I think you know all you need know about me...is that all?" Outside, Jake will aggressively accuse her again of "hiding something," but he abandons her, drives away in frustration too quickly to hear her calling after him. What has frustrated him? Even though he is in the arena of his expertise, there is something about Evelyn that does not conform to Jake's idea of what the situation should look like. He probes her private life, accuses her of withholding information, and suggests that he knows best how a woman in her circumstances should respond. Yet Jake's professional attitude does not here provide results, Evelyn cannot be adequately "read" in accordance with his pictures of marriage, women, grief, deceit, secrecy. In response to this failure of knowledge, his only recourse is to leave in anger, as though her unreadability were a personal affront, a form of aggressive withholding.

Cavell describes how a certain picture of our knowledge of others, of other minds, can suggest the skeptical conclusion that we might never know them. According to this picture, knowing another mind is impossible because that mind can keep to itself, withhold from me: "He's in; I'm out. Is something keeping me out, excluding me? He could be" $(1999,367)$. Such a picture fixes the other's mind, or the person, quite literally inside of a body, which itself functions as a wall-a veil, a bandage-making access to the other impossible; moreover, insofar as he keeps me out, he excludes me, an antagonistic refusal. Cavell notes two distinctive features of this picture of our relations with others, features that transform the real frus- 
trations of our relationships-others really can be withdrawn, and they really are separate from us-into metaphysical constraints.

First, in this picture we conceive of knowing another person as knowing what they know (cf. 1999, 102) or experiencing what they experience; and given that we cannot inhabit another's position or live their life, it then seems that we can therefore never know them. If "he can keep his thoughts to himself" and "hide his feelings" (1999, 367), a suspicious picture will conflate knowing those "things" (thoughts and feelings) with knowing him; and again, upon realizing that other people can conceal those things, knowledge of others seems impossible.

As is already clear from this description of knowing another as knowing what they know, this picture describes the problem of knowing another as a problem of access; this is the second feature. We imagine the other's mind as, for example, "a garden which I can never enter" $(1999,368)$, and in so doing we literalize our genuine experiences of separation or powerlessness $(2002,261)$; we take our feeling of inability with respect to another person and conclude that there is some thing we cannot do (i.e., enter him). With this picture, the real practical difficulty of coming to know another is disavowed and replaced by a speculated metaphysical limitation. We generate an idea that "to know or be known by another is to penetrate or be penetrated by another, to occupy or be occupied. This idea would be prepared by the idea... of the self as private (hence, as said, as guilty)" (1999, 470).

That a PI's business is to find evidence for guilt, that his methods involve invading privacy in order to disclose what his target knows, that the only way to know another person is to produce evidence of her personal life, to occupy her personal space, and in so doing undermine any attempt at hiding or deceit, all this makes the PI a ready exemplar of the skeptical position as Cavell understands it. It is Cavell's contention that oftentimes a philosophically or metaphysically backed skepticism represents a defense against the ordinary disappointments that characterize human relationships, the everyday ways we fail to recognize, listen to, or acknowledge one another. Metaphysical limitations are preferable because ordinary limitations and difficulties are our responsibility. It is easier to hold that we cannot know each other than to accept that, in some cases, we simply do not or will not.

Jake assumes that something determinate, like a secret, is keeping Evelyn from being fully knowable to him, that they are separated for some reason (cf. 1999, 369); as a detective, he assumes that she is withholding 
what she knows, that she is resistant to his questions because she has some thing to hide. Since, in Jake's world, a human being is a source of evidence to be penetrated, and because resistance or withholding communicates a guilty disposition, Evelyn's evasiveness and her direct appeals that Jake stop questioning her can only be interpreted as an admission of guilt and so a solicitation for further invasiveness; there is no possibility, as far as he is able to see, that Evelyn might have a good, not guilty reason to keep things to herself. On a PI's model, human relationships only take the form of interrogation and confession, where privacy is secrecy, and secrecy guilt. For this reason, noirs are especially adept at working out the skeptical picture of knowing other minds.

Jake thinks he knows what it is he doesn't know. And he thinks he can obtain that knowledge as he obtains all his knowledge: invasively, suspiciously, accusingly, and calculatingly. When Evelyn asks him why he wants to know what her middle initial stands for-it is C for Cross, her father's name, something she bears- he says, "no reason, I'm just a snoop." That is, in being suspicious of everything by trade, no question stands in need of any specific justification. Jake's professional suspicion licenses him to ask any question he likes, no matter the cost for whomever he's interrogating.

If, following Cavell, skepticism masks a more fundamental disappointment or even horror in response to the exigencies of human relationships, then we might say that Jake is attempting to know Evelyn while evading the costs or consequences. He just wants to know (he's "just a snoop") the intimate details of her life, the nature and cause of her feelings toward her dead husband and toward her father, where she goes at night, the nature of her relationship with the young girl. He wants to know all of this, believing that he has the right, and that she, given the circumstances (murder and extortion), has a duty to tell. Despite the many signs she gives, both intentional and involuntary, that the aspects of her life that she wants to keep private have no bearing on his case, in generalizing his skeptical detective's attitude Jake assumes that he has right of access to Evelyn, to know what she knows, without any duty to take on the consequences of so knowing. He wants to know her irresponsibly. In fact, as viewers, so do we.

One of Cavell's central ideas in his The World Viewed, where he outlines his ontology of film, is that photography and film "maintain the presentness of the world by accepting our absence from it. The reality is a photograph is present to me while I am not present to it" $(1979,23)$ : a world so viewed 
is a world without me. The cinema, Cavell suggests, provides pleasure, not by endowing the viewer with unlimited power - say, a voyeuristic power to view the world at will—but by providing us a time and space without the need for power, an experience where we do not have to bear the burden of power (ibid., 40). We can be witness to a world without responsibility.

While Cavell has reservations about cinematic modernity, and the idea that movies eventually come to reflect on their conditions, he also observes that "film has brought itself into question" (ibid., 123). That is, it seems that at a certain point in its history or development, film lost its conviction in its promise of a candid exhibition of the world itself (ibid., 119). In this post-lapsarian state, movies are now tasked with voicing this wavering conviction within the strictures of narrative cinema itself. ${ }^{7}$

Now it might seem that film's full realization or acknowledgment of its conditions and capacities must involve a form of conspicuous selfawareness or self-reference, by, for example, calling attention to the camera's interventions. The point, for Cavell, though, is not that the camera should acknowledge its presence in the world it records, by, for example, putting a camera in the scene itself (or putting the director in the film, as Polanski himself does); rather the point is that the camera is absent from the film's world. As Cavell puts it, the camera's calling attention to itself or otherwise winking to the audience "is not an acknowledgment but a denial of withdrawal. You cannot sidestep the claims of a position with a trick" (ibid., 130). This means that "the camera must now, in candour, acknowledge not its being present in the world but its being outside the world" (ibid.). By extension, we the audience must acknowledge not our secret involvement or implicit sanctioning of this world, ${ }^{8}$ but our absence

${ }^{7}$ A full discussion of film's avoidance of the condition of modernity would take me too far afield, into topics of theatricality, automatism and mechanism, presentness, and so on. For my purposes, I think it is sufficient to make note of Cavell's concern about film's taking on the burden of modernism, while at the same time pointing out that he nonetheless sees that such a burden is being assumed.

${ }^{8}$ Michael Haneke, for instance, is an example of a filmmaker who takes it that his task is to bring to the viewer's awareness her secret and ongoing endorsement of what she sees. He is concerned to make the viewer feel the full extent of her power as a viewer, a power he thinks is suffered through the grueling violence in his films, and a power he thinks would be best exercised by walking out of his movies. Though I think he has matured beyond the interrogative and direct-address techniques of Funny Games, even in a film like Caché, he calls the camera's presence in that world, and so our presence, to explicit attention, suggesting that by revealing or unconcealing the camera and its powers to reveal and record, so too are we revealed to ourselves, we are asked to face up to our power as viewers. This is precisely neither the predicament nor the task of cinema for Cavell. 
and powerlessness. But if recognizing presence seemed to call for a kind of self-conscious display, what would it mean to recognize absence? And what of that absence? Just what about absence needs acknowledging?

Cavell suggests that in making a world present to us in our absence from it, film relieves the viewer of the burden of power. I suggest that film thereby fulfills or plays out a certain fantasy of irresponsibility: it permits us to look and to know without consequence. What needs acknowledgment (which is not the same as calling for correction) is our passive presence with respect to a film, and the kind of relationship to knowing and acknowledging, or the fantasies of such a relationship, this passivity might invite.

Noir is perhaps especially apt for exploiting this fantasy of moviegoing insofar as one of its orienting thematic preoccupations is the fantasy, and impossibility, of separateness or neutrality as a condition for knowing. Indeed noir consistently suggests that it is the protagonist's fantasy of his own distance from the object of his interest that will be his ultimate undoing. The Big Heat, for instance, demonstrates this with devastating force: Det. Bannion assumes that he can investigate with immunity a sergeant's suicide and its connection with the mob, that he can face human criminality and cruelty within the confines of his profession while leaving his home life untarnished. In light of this fantasy, his wife's murder (intended for him) represents an assault not only on his effort to reveal the relations between the police force and the mob, but also on his conviction that he could maintain distance, that he could attain profoundly consequential knowledge without personally bearing any of those consequences. It is also an assault on his belief that the only person he puts at risk through his efforts is himself, as though in his investigation he could extricate himself cleanly from those with whom he is otherwise inextricably bound.

Noir's dark suggestion that no human knowledge is born without burden can be understood as, in part, a reflection on and challenge to one of the conditions of cinema, the viewer's belief or fantasy that she will not suffer what she sees, or that aesthetic suffering is somehow not real. In Chinatown, the painfulness of Evelyn's revelation and of the film's final scene is that in both we must recognize in ourselves the assumptions we'd made about her (like Jake, we thought we knew the kind of thing we didn't know) and about our own immunity from involvement or burden. Here, cinema's promise of passivity, its promise to relieve us of our need for power and grant us a kind of knowledge without responsibility, does not finally provide the satisfactions we perhaps felt entitled to. 
Cavell writes that "being human is the power to grant being human" (ibid., 397). His point is that no fact or bit of knowledge will convince one of another person's humanity. Rather, seeing another person as human or in their humanity is something it is in our power to do and also in our power to refuse. But Cavell's point is also that if I withhold my power to grant being human, not only do I fail adequately to acknowledge others, my own humanity is also thereby compromised.

There is no better figure of a compromised humanity in Chinatown than Noah Cross. Of course, Evelyn is the one who is truly compromised, yet in attempting to maintain her privacy, in her effort to assert her separateness even in her intimacy with Jake, in her care for her daughter, in all this Evelyn demonstrates her humanity while it is everywhere denied by others. But the specific nature of Cross' cruelty proves his almost total incapacity for acknowledging others, thus the almost total loss of his own humanity.

Cavell suggests that what spurs skepticism is a disappointment with the criteria for knowing the world and knowing others. With respect to the latter relationship, the sense of disappointment in criteria is itself a response to human finitude or separateness: it is disappointing that no amount of knowing or intimacy can finally overcome our separateness. Being with others places "infinite demands on finite resources" $(1999,470)$; we are asked to live with unknowing as a constant feature of our knowing, to accept privacy as a condition for intimacy, separateness as a condition for attunement. Cavell's thought is that when these demands are felt to be intolerable, we imagine how we might be relieved of them, by fantasizing ways of overcoming our condition and conceiving our practical burdens as metaphysical limitations. Again, the fantasy Cavell returns to again and again is one in which the other is metaphysically walled off from me and the only way I can reach her is by penetrating that barrier.

"It is to be expected that the idea of knowledge as a violation of privacy (or punishment for it) will be eroticized, enacted in forms of sexual life" $(1999,470)$ writes Cavell. He notes sadism and masochism as evidence, and we should also recall Melanie Klein's concept of the "epistemophilic instinct" (Klein 1987, 69), an aggressive response to the (m)other's separateness that expresses itself as the desire to access her body and know its contents. It is possible to understand parent-child incest, or even less extreme dissolutions of generational, familial boundaries, as an inversion of this instinct, a destructive parental response to an awareness of the child's growing autonomy and separateness, a response that views separateness and privacy as 
a violation of the bond. With this anxious interpretation of otherness, access and symbiotic union present the only solution.

Noah Cross is in fact everywhere governed by a bloated sense of his entitlement to access, to literally cross all boundaries: social (both in his incest and in his desire to privatize and own crucial human resources), generational (in his relationships with Evelyn and Katherine), geographical (in his plans to "incorporate" the valley into the city of L.A.), and temporal (in his desire for immortality, for nothing less than "the future"). As the only character in Chinatown with knowledge of both stories (his corruption of the city and his corruption of Evelyn), Cross represents the literalizing or living-out of the fantasy of total access and the possession of complete knowledge. Indeed, while Cross is only in three scenes (his lunch with Jake; the confrontation at Evelyn's house; and the showdown in Chinatown), his presence saturates the film: once one knows what he's done, and so knows what Evelyn wants to keep private, it begins to seem like his terrifying omnipotence haunts every scene. ${ }^{9}$

Following a device common to many noirs, Jake finds his double not only (more obviously) in the thuggish hired gun Mulvihill, and in Lt. Escobar, an old colleague and newly appointed lieutenant; Chinatown also suggests a relation of doubling or kinship between Jake and Noah Cross.

In noir, doubles often offer glimpses of how life for the protagonist might have been, and thereby offer a distorted kind of mirror or opportunity for reflection; additionally, these doubles add to the uncanny, nightmarish quality of noirs, lending the world of noir a tenor of inescapability (David Lynch's films, for instance, take this element of noir and exploit it to hallucinatory effect). Attending to the relations of solidarity and mutual mirroring that are articulated between Cross and Jake allows us to see Cross as a fully realized, exaggerated version of the kind of posture adopted by Jake. That is, Cross represents the very omniscience Jake desires. Indeed, by consistently describing Evelyn as a "disturbed woman," Cross presents himself as a better authority on her state of mind and sense of self

\footnotetext{
${ }^{9}$ Another fictional character that similarly embodies this superhuman, almost metaphysical degree of power and control is The Judge, in Cormac McCarthy's Blood Meridian. Both men have perverse sexual appetites, both wield uncanny control over the events in which they participate, both desire, and take, the future; and both stories concern something like the founding or the maintenance of America, where being an American male licenses one to access all (the West, the people in it, the future).
} 
than she is (as Jake had done when he judged her to be "upset but not that upset"). In so doing, Cross intimates that he knows what she knows, which is just what Jake seeks.

As we will see, consulting Cross constitutes Jake's greatest betrayal of Evelyn. In many noirs, the plots and more general thematic orientations pivot around a betrayal of intimacy; usually another character, often a woman, either betrays the protagonist or is seen to. With such a betrayal revealed, we are exposed to the thought that any human relationship is an opportunity for manipulation and capitalization. The femme fatale uses what she knows about the protagonist to exploit the relationship as a means to some end. And in films where the woman we expect to betray the hero does not (e.g., Gloria Graham's character in The Big Heat), the protagonist and audience must live with the guilt of having assumed her duplicity; that is, in assuming her deceitfulness, it is we who have reduced intimacy to manipulation, it is our faith in expressions of solidarity and offers of friendship that has weakened. In Chinatown, insofar as the audience also looks to Cross as a possible source of insight into Evelyn's secrets, by the film's end we also must live with the burden of having assumed her duplicity, of having conflated her privacy with some imagined guilt, of having believed that her father, of all people, could help us understand her. Doubting Evelyn's account, and turning to Cross for his, constitutes exactly the kind of "second injury" that victims experience when their claims are not heard or treated as authoritative (see Walker 2006). We see evidence of the impact of this second injury when, upon hearing that Jake went to see her father, Evelyn covers her naked body and recoils from Jake, her face crumbling in pained incomprehension.

If noirs frequently suggest that objective or complete knowledge is no longer possible, Chinatown recognizes that, when indulged, absolute knowledge takes a horrific shape. As Cross calmly informs Jake, with regard to the "loss" of his daughter: "I don't blame myself. You see Mr. Gitts [Cross never correctly pronounces Jake's last name], most people never have to face the fact that at the right time and the right place, they're capable of anything." With this it seems clear that the omniscience and omnipotence we thought we wanted is realized here in a frightening capacity to do "anything," which is to say a total incapacity to recognize anyone that would stand to suffer from that power, anyone who would constitute a legitimate limit to that capacity. With Chinatown, we discover that the absolute success of knowledge and power is not "humanly satisfying" $(1999,455)$, it denies the finitude, which is to say the humanity, in 
oneself by denying the authoritative presence and demand for acknowledgment, which is to say the humanity, of others.

At the beginning of my discussion of Chinatown, I suggested that there were really two films here, two stories or two worlds. I said that in our efforts to make sense of the first, we miss the signs of the second, which is to say that in our effort to secure knowledge, we neglect a claim to acknowledgment. Now it is standard in Hollywood filmmaking to run two parallel plots: the "action" plot and the "romance" plot. ${ }^{10}$ But Chinatown's second storyline isn't exactly Jake's and Evelyn's romance, as it is simply Evelyn's story, and though her brief intimacy with Jake is part of it, that intimacy is not its central current or point. Evelyn's story concerns the threat of her life unraveling (again) thanks to the investigation of a nosey PI; it concerns her recognition of him as someone similarly suffering from the past, and his consistent misrecognition of her; finally it concerns her compassionate struggle, against the efforts of her father, to maintain in her daughter a lack of knowledge, as part of her effort to ensure for her daughter and herself the future to which Cross feels cruelly entitled. In each of these efforts, what is owed to Evelyn is some form of acknowledgment.

As should be clear, my own discussion-in its concern to clarify Jake's project and the idea of knowledge that governs it, and in its effort to indicate how cinema itself plays out a certain fantasy of knowing without responsibility — has also sidelined Evelyn, not yet acknowledged her. It is as though consideration of Chinatown repeats the very dynamic of misrecognition staged by the film itself, as though a preoccupation with everything besides Evelyn was our fate as viewers, until it is too late. That our evasion of Evelyn constitutes such an instructive failure of acknowledgment helps clarify why Cavell thought that concept could be equally well elucidated by its failure as by its success: we learn something about what acknowledgment is when we can recognize its absence. What, then, would it be to pay attention to Evelyn? Can Chinatown also tell her story?

${ }^{10}$ Thanks to Daniel Morgan for calling my attention to this. 
If we can see in Chinatown also the staging of her story and not just its consistent neglect (and I am still not sure if we can), ${ }^{11}$ then how we tell her story will be quite different than how Jake's is told. The plot of which Jake is the hero, however anti-heroic and unsuccessful he may be, is told in his actions (even if failed) and through the circumstances in which he finds himself: we follow Jake's story by following what he does, what he looks at, or by learning what he knows (often as he comes to know it); we follow him into reservoirs and orange groves and public hearings, and we work alongside him to piece together a story. That is, in order to know him, we attend to the world toward which he is actively oriented. For all this outward-facing action, there are really only two moments when we are asked to consider Jake as a character with an inner life and a history: the first is in bed with Evelyn, the second is in the film's closing moments.

For the most part, Evelyn's story is told, not primarily by what she says and does as either a self-determining agent or an agent struggling to be so (like Jake), but rather in her face, in the ways in which it speaks for her and in spite of her. Viewing the film again, that is, after one knows what she is trying to both keep to herself and communicate, it is striking to see how much is there on the surface of her body. While we cannot know Evelyn by looking at the world around her, we do not for that matter have to look into her, to access her mind or know the contents of her thoughts; rather we can look at her face. There, we can quite literally see her struggle to inhabit two worlds, to play a part in two stories-hers and Jake's, or hers and the rest of the world's-right there in her faltered gaze, or in her stutters, or in her clenched jaw.

Or again, at Jake's mention of her father in the former's office, Evelyn blanks, and in attempting to recover herself, she lights a second cigarette, her first still burning in the ashtray. When Jake asks if his mentioning her father upsets her, she launches into a canned explanation having to do with a fight between her father and her husband, but stutters on the word "f-ffather," her face slackening, deadening, as she does so. It looks as if the film has frozen her in an awkward moment between determinate movements or expressions, as though the photograph was taken a moment too

\footnotetext{
${ }^{11}$ A worthy question for another paper on Chinatown would be whether we could regard it as representative, at least in part, of the melodrama of the unknown woman. See Cavell's Contesting Tears: The Hollywood Melodrama of the Unknown Woman. University of Chicago Press, 1997.
} 
late or too soon. Yet while I think she $i$ s occupying something like an inbetween zone, between being present with Jake and following out her associations with the word "father," she in fact holds this look for several seconds. That is, this look is part of her repertoire of looks; as a moment between determinate expressions, this is itself one of her forms of communication. Only with multiple viewings is one able to see how consistently Jake fails to really look at her face. And so while the film as a whole makes possible an aesthetic understanding of acknowledgment, this is in part by way of staging Jake's lack of aesthetic intelligence, his inability to look and see what is there on Evelyn's face.

Writing on Cavell's work on photography and film, Richard Moran argues that by simply placing a human being in its range, the camera will find there forms of expression unknown or unendorsed by that person. As he writes (Moran 2016), speaking of a character in Terrence Malick's Badlands: “the very fact of the camera's presence makes his very inarticulateness, the very grain of his silences and hesitations, into unavoidable vehicles of expression" (30). This inevitable expressivity, or to put the emphasis on the other side, this endless legibility, is both liberating and confining, "since within [the camera's] gaze, not even holding still and keeping silent, can count as withholding expression" (ibid, 31).

For Wittgenstein (2001), the body, photographed or not, stands as "the best picture of the human soul" (178); as Cavell puts it, "the soul is there to be seen" $(1999,368)$. Photographic media make explicit or thematize this fact of animate embodiment, namely that the body is not a veil but a voice for the soul. But if the soul really is there on the surface and in the movements of the body, Cavell continues, then "what hides the mind is not the body but the mind itself" $(1999,369)$, and that may be the other's mind or my own. That is, hiding myself or missing another are not our fates but our capacities, possibilities for our form of life; if this is so, then if we are unknown to one another, this isn't because we are confined within veil-bodies but because being unknown is a human possibility: we can wear veils or fail to look, but "we have a choice" (ibid., 107).

Evelyn then is concealing herself, is withholding from Jake, yet this work, the effort of which manifests in stutters and glances and fidgeting, functions against her best intentions by giving her away, or at least by making herself available to be read and acknowledged. In every instance, however, Jake is ready to account for Evelyn's apparent eccentricities with a story that fits what he already has in mind, which is to say that he exactly 
fails to read the expressivity of Evelyn's face. When, for example, Evelyn is beside herself and confesses that the girl in her house is her sister-she claws at her own hair, knocking her head portentously on the car's horn, a foreshadowing of her fate in the final scene-Jake responds to her intense remorse, first, by accusing her of being unnecessarily secretive ("take it easy-she's your sister, she's your sister. Why all the secrecy?"), then, after Evelyn cries quietly that she "can't," he takes the opportunity to answer his own question: "is it because of Hollis? Because she was seeing your husband? Is that it?," to which she eagerly nods her head, gratified for Jake's story, for the shift of attention away from her, back to, essentially, himself and his ideas. This is in fact their dynamic for much of the film: Evelyn, intentionally or not, gives something away, and Jake, rather than pay attention to her, uses this as material for his own speculative construction. In his professed effort to know more about her, he turns away from her, more interested in his own theories gleaned from his prized expertise; to this we want to say, with Wittgenstein (2001), “don't think but look!” (\$66). We might call this Jake's urge to misunderstand (ibid., $\$ 109$ ): he has brought a picture of how to understand Evelyn and cannot get outside it, he will not allow that Evelyn, and whatever she has to tell, might be capable of shaking his beliefs.

Chinatown provides us with one scene of intimacy, one moment of possible friendship. It is, of course, almost requisite for the protagonist of film noir to become emotionally or physically entangled with a woman involved in the case; such couplings, while they may relieve a kind of building tension between the characters and in the audience, nevertheless spell doom for the hero, dashing whatever hope he may have had for extracting himself or surviving the case unscathed. This is true of Chinatown, but this scene also offers a glimpse of something like another way in which Evelyn and Jake could be together. So while it does seal both of their fates, this moment is especially tragic because it also seems a fleeting respite from their fate, an opening, however brief, of a space for mutual acknowledgment. But this space cannot be maintained, and its imminent end is kept in view from the start: as the swell of music dies down, a stopwatch can be heard ticking throughout their quiet conversation in her bed.

What is important about this scene is not that Evelyn and Jake have sex, but that here Evelyn is finally doing the talking, and she is asking the questions. Outside on her patio, following their day of investigating the orange groves and being attacked at the retirement home, Jake toasts her 
for saving his “a-a-.., for saving my neck," correcting his vulgar language yet again, inspiring a sympathetic, even endeared smile from Evelyn. She asks him whether this often happens to him, clarifying that she means this kind of active afternoon, and he, gazing and smiling at her says, "actually this hasn't happened to me in a long time." This provokes a series of questions from Evelyn, where she turns Jake's own defense against him-“it's an innocent question"-and in this exchange we first hear about Chinatown, where Jake did "as little as possible." When Evelyn asks why he left, Jake touches his wounded nose and asks for peroxide.

Inside Evelyn tends to his cut; "it must be painful," she says, and in response Jake asks what's wrong with her eye-“"there's something black in the green part of your eye"-again, deflecting attention from himself as an object of inquiry or concern. As he looks intently at her, she holds his gaze and smiles genuinely: "oh that. It's a f-f-flaw, in the iris," stuttering over "flaw," like "father." They embrace. In bed, the clock ticking, Evelyn turns to ask Jake, who faces forward, whether he wore a uniform, saying he must have looked cute in blue and she says, looking at him, "I want to know more about you." When he says "not now," she replies, "you don't like to talk about the past do you? ... why does it bother you to talk about it?" He says it bothers everyone that works in Chinatown, because “you can't always tell what's going on; like with you," making explicit that what bothers him about Evelyn is nothing about her as a person but that he can't tell what's going on, that he feels powerless and confused, a representative experience of the motivation for skepticism. As he says this, he turns to face her, and now Evelyn shifts to face forward, as though their proximity would be too much to bear if they were face to face. When Jake explains to Evelyn what happened- "I was trying to keep someone from getting hurt; I ended up making sure that she was hurt"- they do face each other. Jake's description can be interpreted as a memory, a comment on their present circumstances, and a prediction.

What does Evelyn want to know about Jake? In a sense, this scene represents her turning the tables, putting Jake on the receiving end of intimate questions. It might seem that, like his questions regarding Evelyn's feelings for her father, Jake experiences these questions about Chinatown as invasions of privacy or suspicious inquiries. But if this is a correct description of Jake's experience-and his response to her that he's "tired" indicates his real discomfort-it seems that his is a partial, or defensive, assessment of their exchange. For what Evelyn wants to know is not the 
kind of thing Jake wants to know, or her wanting to know is not animated by the same suspicious spirit. What Evelyn sees here is an opportunity for friendship, not for confession, whereas Jake's only understanding of conversation is as interrogation. That is, he can only understand an intimate relationship from within the perspective of his professional métier.

In the penultimate chapter of The Claim of Reason, Cavell explores skepticism of other minds, and proposes that it is properly conceived as consisting in two forms, active or passive skepticism: the former characterizes the more familiar form of skepticism regarding others and whether one can know them, the latter represents skepticism as to whether $I$ can ever be known by others. Cavell then not only clarifies what it is we want, as opposed to what it is we think we want, when it comes to knowing another; he also meditates on what would count as being or feeling known. And as Moran rightly develops this thought, when it comes to human beings (as opposed to things) we have a say in whether we are truly known, one must be able to "find oneself in the knowledge that others claimed to have achieved" (Moran 2011, 252): to really be known, one must feel known. Trying to make sense of what it would mean to feel known, or find oneself in others' knowledge, helps dissolve the illusion that knowing others has anything to do with access, it makes "the fantasy of 'peering into the mind of another' seem not just fantastical and out of reach, but as missing the fact of how the knowledge of another is a matter of relatedness or responsiveness to that person" (ibid., 251). Taken from the other side, it makes the fantasy of, say, "opening up to the gaze of the other" (or being opened up by it) seem likewise misguided (and both versions now seem quite paranoid). Reconceived with Cavell, being known by someone not drive by this fantasy of access makes that person "not an ideal Confessor (because to a Confessor one must confess, make oneself known) but an ideal Acceptor...the Friend" (ibid., 460).

When Evelyn looks at Jake and asks about his past, it seems like she is trying to be a friend, not a confessor; she wants to know him and not "what he knows." It also seems that precisely in his reluctance to talk, a form of withholding that gives him away as someone with a past painful enough to suppress, Evelyn perceives in Jake someone with whom a kind of understanding might be possible. That is, she sees a kindred spirit, someone who likewise suffers from memory, who withholds from others (recall that she's told Jake that she "never stays with anyone very long"); she 
gazes at him with a longing not to possess but to understand or acknowledge, that is, to connect in the balance of separateness and intimacy. ${ }^{12}$

But the attraction of wounded people to wounded people is often animated by a fantasy of mutual recognition shaped by those very wounds; that is, with this fantasy we are in the grip of repetition, despite imagining that we are working through it. So if Jake is governed by a picture of knowing as accessing, and if, as we have seen, Noah Cross is likewise so governed, then Evelyn's attraction to Jake is in part a repetition of the dynamics with her father. After all, she is attracted to a man whom she has attempted to fight off or reject (she asked him to drop the case, she asked him to stop questioning her), who has not respected but in fact feels entitled to her privacy, who is crude (Jake uses foul language; Cross tells Jake he likes his "nasty reputation") and self-absorbed (both Jake and Cross are concerned primarily with their own success). So despite the perceived promise of acknowledgment, despite Evelyn's holding out for a friendship with Jake, in fact nothing suggests that this could be anything but painful, and familiar. And for Evelyn the familiar does not comfort, and if it can, then for the wrong reasons.

In any event, the clock is ticking, and their conversation about Jake's past is interrupted by a call from what we might understand as both her past and their future or fate. The rest of the film is an unfolding of that destiny, from her revelation of her sister/daughter, to Jake's confrontation of Cross which leads to the reunion of Cross and Evelyn, to Evelyn's death and Cross' absconding with Katherine. Though in some way a respite, Evelyn and Jake's union in fact solidifies their capture in repetition: she

\footnotetext{
${ }^{12}$ Obviously, in imagining what she wants, I am taking some interpretive liberties here with the character of Evelyn. Yet from what we know about her, and what we know about people, I think this interpretation is fair. On the topic of the relationship between how we understand what we and others do, and how we understand characters in movies, Robert Pippin (2012) writes: "there are certainly great gaps between [these cases]... but while screen images are not persons, and film narration is sui generis, there cannot be two completely distinct modalities of such sense-making: one for ordinary life and another governed by an incommensurable movie or dramatic or diegetic or aesthetic logic" (2). Being able to regard and understand movie characters in accordance with the same logic or framework with which we understand ourselves and others is, as Pippin puts, "the minimum conditions for the intelligibility of filmed action" (3). If we can understand Evelyn's lying in bed, speaking to Jake, as action, then I think it is fair to bring to bear both what we know about who she is and what she's done or been through, and what our best thinkers have to say about human motivations and experience, in order to imagine both what she is doing and what she takes herself to be doing.
} 
repeating the dynamic of resistance and penetration enacted with her father, he repeating by endangering someone he cares about through his very efforts to care. To use words of Cavell's meant for another of Polanski's films, here we feel "the power of the past to join hands with the future behind the back of the present" $(1979,87)$.

When Jake finally confronts Evelyn in the house where Katherine is kept, he is again certain that he knows some secret that Evelyn has been keeping; moreover, he is again certain that in so keeping it, her biggest crime is putting him at risk, this time by putting his detective's license on the line. By this point in their relationship, his suspicions and selfishness seem especially cruel, even punishing. After being forced to confess the nature of her relationship with the girl, Jake thereby reinstating their dynamic as one of interrogation and confession, not friendship, and after he responds to her confession by beating her, Evelyn sits on the couch and draws it all out. "My father and I..."-and here she juts her face toward him, taunting him, indignant that he has demanded so much from her"understand? Or is it too tough for you?"

When Jake states (he does not ask) that her father raped her, she looks at him both pleadingly and pityingly, as though it would be so easy if that's all it was, as if rape would be a much simpler thing-and then she shakes or twitches her head, and it isn't clear whether she is disconfirming his statement or rejecting his gaze, rejecting the place to which they've come. When Cavell insists that the soul is there to be seen, or that only the mind can hide the mind, he is, to reiterate, not suggesting that this makes knowing or acknowledging or showing a soul an easy task, but he does mean that the body is where the full complexity of the soul will show itself, if it does: "nothing is hidden" (Wittgenstein 2001, \$435).

In "Knowing and Acknowledging" Cavell asserts that "from my acknowledging that [for example] I am late it follows that I know I'm late (which is what my words say); but from my knowing I am late, it does not follow that I acknowledge I'm late-otherwise human relationships would be altogether other than they are" $(2002,257)$. Acknowledgment, on Cavell's understanding, is logically dependent knowledge and goes beyond it, "not," he qualifies "in the order of knowledge, but in its requirement that I do something or reveal something on the basis of that knowledge" (ibid.). My acknowledgment that I am late, for example, takes responsibility for 
what I (we both) know, owns up to a failing, responds to your disappointment, develops what could be a merely epistemic awareness into a component of an ethical relationship.

In a sense, then, Jake does, or tries to, acknowledge Evelyn when he responds to her narrative with a flurry of activity. With his new "knowledge" ("he raped you"), Jake immediately tries to do something about it, to help Evelyn by arranging for her escape. Because he understands what's happened as the acquisition of important knowledge, Jake thinks there is something he can do about it. Additionally, Jake feels the need to do something for himself: he decides to confront Cross - to assuage his own guilt by insisting that Cross face his - a confrontation which will ultimately lead Cross to Evelyn, to Evelyn's death and Katherine's abduction. Thus Jake works to go beyond his mere knowledge by doing something practical, attempting to exorcize or exercise knowledge through the efficacy of action.

As I have been arguing, however, it appears that Jake does not successfully acknowledge Evelyn: he remains too committed to the orders of knowledge and action-qualifying her experience as (simply) rape, acting on this new knowledge by confronting her "rapist" - to properly acknowledge her, to attend to what she might want or need or how she might conceptualize her experience. Her derisive eye-roll in response to Jake's conclusion that her father raped her, and her conviction that the police can do nothing to help her because her father "owns the police," suggest that in her world knowledge and action are not domains that offer any opportunity. Indeed, the nature of Cross' abuse, their ongoing relationship, and the extent of her traumatization suggest that knowledge and action have been devoid of their potentiality, Cross having established himself as in firm control of both spheres of human life. Is Cavell correct, then, in claiming that acknowledgment "requires" that I do something on the basis of knowledge? Is he right that real acknowledgment rests on knowledge? Might not launching into action based on what he "knows" be precisely another way in which Jake avoids the profound difficulty of acknowledgment?

If the concept of acknowledgment is not given in advance but evidenced in its instances, if in appreciating acknowledgment we must not think but look and see, then from the case that Chinatown presents it would seem that we may need to amend or reject Cavell's provisional requirement that acknowledgment involve knowledge and action. Perhaps, instead, we can imagine gestures of acknowledgment that are not predicated on knowing and doing. ${ }^{13}$ What would be acknowledged by such

\footnotetext{
${ }^{13}$ I am very grateful to José Medina for this suggestion.
} 
gestures would be not what one knows and can do, but what one can stand not knowing and not doing, so it would acknowledge the space of separateness and the limits of action. Evelyn herself recognizes that acknowledging her daughter involves protecting her ignorance, at least for now. Might acknowledging Evelyn also involve Jake accepting his ignorance? Jake could then know that Evelyn was raped-whatever he thinks that means exactly - and still accept the limits of what that tells him, hence what he knows, hence what he can do about it. Acknowledgment without knowledge might then express a kind of trust: Jake's trust that Evelyn has reasons for her insistence on privacy, which might in turn inspire Evelyn's trust in Jake's ability to accept, to acknowledge her. This form of acknowledgment might be minimal, but when the world is such that knowledge and action can be so swiftly corrupted, a different requirement for acknowledgment might involve a capacity for silence and stillness. This would also indicate a domain of practical, ethical life that did not so immediately funnel us into actions and projects.

In one of the first scenes of interrogation between Jake and Evelyn, the former pressing for more information and confession from the latter, Evelyn fabricates the story of her affairs in order to divert Jake's penetrating attention. There is, though, an element of truth in her lie when she states, "I don't see anyone for very long, Mr. Gittes." With this, Evelyn reveals the cost of Cross' abuse, its disrupting the possibility of her being with others, since presence to others seems to require a revelation of her history for which she is not prepared; seeing anyone commits her to being seen, which she sees as too risky. As we have seen, Jake can only interpret Evelyn's privacy and reticence as secretive, guilty. Of this (mis) interpretation of what's involved in acknowledgment, Cavell writes:

If the need to acknowledge presents itself as an urge to confess, it may therefore present itself as an urge not to, an urge to secrecy. Then one will have to have something to keep secret. Hence the crime, if only of imagination, will be for the sake of the guilt. For in a disordered world guilt will be proof of privacy, hence of one's possession of a self, hence of the nature of one's self. It will be the making known of oneself to oneself. So the desire for sanity can drive one mad. $(1999,460)$

If the knowledge required for acknowledgment is expressed in the mode of interrogation and confession, acknowledgment may be avoided for that reason, with the need for acknowledgment recoiling and giving rise to a need for secrecy. Here the one who seeks to be acknowledged retreats 
under the threat of exposure, that very retreat functioning to organize the self around what is now kept as a secret, and so kept guiltily. It would seem that it is in an effort to avoid this dynamic of intimacy and avoidance, exposure and withdrawal, needfulness and guilt, that Evelyn wont "see anyone for very long," her apparently guilty withholding a testament to her real need of acknowledgment.

Jake and Evelyn are thus trapped in this self-satisfying circle: Jake's suspicion of guilt is confirmed by her evasiveness, Evelyn's fear of exposure and vulnerability is compounded by his interrogation. My suggestion is that so long as they are gripped by the economy of knowledge (and action), Jake and Evelyn will miss their opportunity for acknowledgment. Against some of Cavell's own claims, then, it would seem that acknowledgment can but need not (it is not a "requirement") be based in knowledge or find completion in action. In certain cases, acknowledgment may find expression in the ability to tolerate not knowing, or in a willingness to suspend the drive to do something.

Recall Cavell's words: “in a disordered world guilt will be proof of privacy, hence of one's possession of a self, hence of the nature of one's self. It will be the making known of oneself to oneself. So the desire for sanity can drive one mad."

Chinatown's world seems something like a "worst case" of the kind of "disordered world" that concerns Cavell. With Evelyn's revelation, we see that this particular world is disordered to the point of imminent collapse: if adequate boundaries are a condition for social life as such (even if those very boundaries can drive us to skepticism), then Chinatown offers a vision of a world where such boundaries are destructively weakened. Note that Evelyn never explicitly says what happened with her father, as though whatever possibility for world and future is left to her is predicated on her not invoking that trauma; certainly when Evelyn tells her father that Katherine will "never know" of the conditions of her conception, she is demonstrating her conviction that a world is possible, is fit for flourishing, only without that kind of knowledge. Sometimes ignorance holds space for possibility. This is why, when Jake tries to interpret Evelyn's confession as a story of rape, it seems trite, as though he were trying to turn Evelyn's experience into some readily knowable thing in his still stable universe. He tries to remain unchanged by her revelation, to hold his world together. $\mathrm{He}$ is 
able to sustain that hope just until Evelyn tells him the address of where they are going, and in the film's most ominous zoom, we watch as the realization that they are returning to Chinatown dawns over Jake's face.

We can regard the rest of the film as the gradual unraveling of whatever coherence was left of this world; or rather, it unfolds the consequences of a world of human relationships structured according to the dynamics of skepticism, invasiveness, guilt, confession, corruption, rampant capitalism, gendered violence, and, as I have been suggesting, an ongoing failure of acknowledgment. When Jake stares lifelessly at Evelyn's bloodied body hanging out of her car, when he murmurs to himself, "as little as possible," can we conclude that he's finally recognized the logic that he'd been following all along? Has he realized that in doing what he took to be as much as he could, he did (again) as little as possible, and so failed Evelyn? Is this the face of a man who comprehends that this is the second time he's been at this scene? Can he now acknowledge Evelyn, since, even if is too late for her, his capacity to finally grant her humanity will have consequences for his own? Or will he forget it, since it's Chinatown?

If the film does not answer these questions, I hope to have shown that insofar as Chinatown dramatizes the dynamics of knowing and acknowledging, we know at least that these are the questions that Jake, and we, are left with. As Jake, and perhaps the viewer, is counseled to "forget it," the music swells and the camera arches upwards, scanning the faces of a gathering and curious crowd; a policeman yells into a loudspeaker to "clear the area!", to leave Chinatown, just as a production assistant might instruct the crew to clear the set, or as an usher might ask the audience to exit the theater, to leave Chinatown. It's over. Now we must decide what to do with this experience, what if anything we will let this film teach us, what kind of responsibility - aesthetic? ethical? - is required in order acknowledge this world without us. Cavell writes that it is through fantasy "that our conviction of the worth of reality is established" $(1979,85)$. If this is so, and if movies offer something like the opportunity for shared fantasy, then we might understand the empty or gutted feeling Chinatown leaves us with as a kind of nausea in response to the prospect of trying to work out in what ways this film has transformed our conviction in the worth of the world.

Chinatown, I've argued, explores the possibility and cost of avoiding acknowledgment, and how a faith in knowledge can obscure just what one seeks to know. Additionally, we can see in Chinatown a consideration of and challenge to the fantasy of passivity we viewers enjoy with respect to the worlds and pleasures offered by the movies. In the cases of persons and 
movies we can ask: what do we want to know, what are we willing to know or forego knowing, when we want to know more about them? The organizing difficulty of this film is that if we evade the ethical and aesthetic demands of relationships, to others and to films, if we are unwilling to see what is revealed to us, then the poignancy and possibility of these relationships is missed. Cavell writes, "the only justification for the knowledge of others is the willingness for complete knowledge. That is the justice of knowledge" (1979, 127-28). We might amend this with the suggestion that this willingness must, paradoxically, include a willingness for incomplete knowledge, a willingness to tolerate the limits of what will be known, or shared, and the limits of what we can do. The unwillingness to take on those burdens, Jake's and our unwillingness, is the injustice of Chinatown.

\section{Appendix}

In 1937 Los Angeles, a private eye, Jake Gittes (Jack Nicholson), is hired by a Mrs. Mulwray to investigate the indiscretions she suspects of her husband Hollis Mulwray, chief engineer of the Los Angeles Water and Power Company. After following Mr. Mulwray, Gittes obtains photos of him with a girl, pictures published in the papers without his consent. As it turns out, the woman who hired Gittes was not Mrs. Mulwray; the real wife of Mulwray, Evelyn (Faye Dunaway), visits Gittes at his office to introduce herself (by confirming that they have never met and that she certainly never hired him) and inform him of her intent to take legal action against him.

The mystery begins here: who was the woman pretending to be Mrs. Mulwray and what was her motive? While Gittes may have been able to maintain a level of distance and professionalism in his work as a PI, this new investigation concerns him personally; his curiosity about why anyone would want to slander Mulwray is second to his desire to know who set him up and to clear his name. In a meeting with Evelyn where he announces his intent to bring this information to light, she tells him that she will drop the lawsuit if he will stop his investigation. When he resists, she asks, "is this a business or an obsession for you?" Eventually, she complies and tells Gittes that he might find her husband at a certain water reservoir. When Gittes arrives, the police are already on the scene, as Hollis Mulwray was found drowned.

The mystery deepens. On the one hand, a murder needs solving, but on the other, there is another even less straightforward problem concern- 
ing Mulwray. L.A. is suffering from a drought, a drought severe enough to bring farmers into the city to protest and accuse Water and Power of stealing crucial resources. Yet in following Mulwray, Gittes discovers that fresh water is being secretly emptied into the ocean in the middle of the night. In his efforts to uncover more information, Gittes is apprehended by another PI apparently under the employment of Water and Power (Gittes' seedier double) and an unassuming heavy (played by Polanski himself) who cut his nose for being "nosey."

As it turns out, Evelyn's father, Noah Cross (played by occasional noir director John Huston), was once a co-owner of Water and Power (along with Hollis Mulwray) before it was turned over to the public. Over a lunch visit, Cross offers to double Gittes' pay to find the girl with whom Mulwray was apparently having an affair, warning that Jake does not know what he's dealing with (advice, Jake muses, that he was given while a cop in Chinatown). Jake discovers shortly after that the drought is in fact a fabrication of Cross', with an end to buying the dried-up land from farmers at a low price in order to later replenish the area (with the water that was never in low supply) and sell it for a profit.

There is, following this development, a respite from the investigation, as Jake and Evelyn make love in her house. The scene is intimate not simply because they sleep together, but because Evelyn tries to find out more about Jake as a person, about his time working as a police officer in Chinatown where he did, as he puts it, "as little as possible." "I want to know more about you," she says, to which he replies that he is tired. He does, however, disclose that Chinatown was a place where one could never quite tell what was going on ("like you," he says to Evelyn), and while he was there he suffered a great loss; in trying to keep a woman from getting hurt, he ended up making sure that she was.

The final, crucial developments happen quickly, and I'll simply lay them out. Evelyn receives a call, her mood changes drastically, and she tells Jake she needs to leave; she also asks that he "trust" her, and warns him that her father is "crazy." Jake follows Evelyn to a house where Mr. Mulwray's girl is in bed and forced to take pills at Evelyn's behest. Confronting her, Evelyn admits, reluctantly and tearfully, that the girl is her sister. In an exchange with a (newly appointed) lieutenant with whom Jake worked in Chinatown (Jake's apparently more respectable double), he is told that Mulwray drowned with salt water in his lungs, despite being found in a river reservoir. Back at Evelyn's house, Gittes discovers that a pond in their backyard is filled with saltwater, and in that pool he finds a pair of men's 
glasses - or, indeed, he re-finds, as, in his first visit to this house, the Chinese gardener told him that salt water is "bad for the grass," which, with his accent, sounds like "bad for the glass."

From here, Jake concludes that Evelyn killed her husband and confronts her at the house where the girl is staying. The most troubling and unexpected and disorienting scene in the film, Evelyn reveals a secret, but not the one Jake believed he would extract from her: the girl is indeed Evelyn's sister, but also her daughter. In response to this, Jake slaps her and screams that he "wants the truth." She answers: "my father and I... [looks him in the eye, I would say cynically]...understand? Or is it too tough for you?" To Jake's quiet response- "he raped you?"-she practically rolls her eyes. Later I will discuss this scene, and its centrality to what I will call the second film, Evelyn's film, at length. But note now that Jake came to Evelyn with a definite idea about how she was betraying him, about the kind of knowledge she's been keeping, about the kind of deceptive woman she is, and about the kind of clarity and satisfaction he will achieve when she tells the truth. Compare these expectations with her revelation. What satisfaction does this provide? What kind of world does this information clarify? What does it mean to know this, to know what Evelyn knows?

Evelyn is planning on running away with the girl, departing from her butler's home in, of all places, Chinatown, the disorienting and unlucky place of Jake's past, where attempts to help only guarantee harm. Of the glasses found in her backyard pond, Evelyn mentions that they did not belong to Hollis, "he didn't wear bifocals." Going quickly now, Jake contacts Noah Cross, making plans to meet him by offering information about the girl Cross had hired Jake to find. In their confrontation, Cross does not deny Jake's accusations regarding his crimes against Evelyn, the city, and Hollis Mulwray. Mulvihill, hired by Cross, puts a gun to Gittes' head, and, after warning that "it really isn't worth it," they force Gittes to lead them to Evelyn. In Chinatown, Evelyn does everything she can to protect the girl from Cross, who claims that the girl is "his too." When Jake calls to Evelyn that he's brought the police to help, Evelyn cries that Cross "owns the police," and gets in her car to drive away. The police shoot her in the head, which lies noisily on the car horn. In the confusion, Cross easily makes away with the girl, covering her eyes to protect her seeing her dead mother; indeed the film calls so little attention to his escape that it is only upon realizing that the girls screams have faded away, that we realize that Cross has re-possessed her. Jake is fully expressionless as he 
stares at Evelyn. Finally, under the lieutenant's orders (“just get him the hell out of here!"), Jake's partners lead him away, and as Jake glances back, one says, in the film's most famous line, "forget it Jake, it's Chinatown." 14

\section{REFERENCES}

Borde, Raymond, and Etienne Chaumeton. 2002. A Panorama of American Film Noir: 1941-1953. Translated by Paul Hammond. San Francisco, CA.

Cavell, Stanley. 1979. The World Viewed: Enlarged Edition. Cambridge, MA: Harvard University Press.

- 1999. The Claim of Reason: Wittgenstein, Skepticism, Morality and Tragedy. Oxford: Oxford University Press.

- 1984. The Claim of Reason: Wittgenstein, Pursuits of Happiness: The Hollywood Comedy of Remarriage. Cambridge, MA: Harvard University Press.

—. 2002. Must We Mean What We Say. Cambridge, UK: Cambridge University Press.

Dederer, Claire. 2017. What Do We Do with the Art of Monstrous Men. The Paris Review, November 20.

Durgnat, Raymond. 1998. Paint it Black: The Family Tree of Film Noir. In The Big Book of Noir, ed. Ed Gorman, Martin Greenberg, and Lee Server. New York: Carroll \& Graf Pub.

Klein, Melanie. 1987. The Selected Melanie Klein. London: Free Press.

Moran, Richard. 2011/2. Cavell on Outsiders and Others. Revue internationale de philosophie, $\mathrm{n}^{\circ} 256,239-254$.

. 2016. Stanley Cavell on Recognition, Betrayal, and the Photographic Field of Expression. The Harvard Review of Philosophy XXIII: 29-40.

Pippin, Robert B. 2012. Fatalism in American Film Noir. Charlottesville, VA: University of Virginia Press.

Schrader, Paul. 2003. Notes on Film Noir. In Film Genre Reader III, ed. Barry Keith Grant. Austin, TX: University of Texas Press.

Thompson, David. 1994. A Biographical Dictionary of Film. 3rd ed. New York. Walker, Margaret Urban. 2006. Moral Repair: Reconstructing Moral Relations after Wrongdoing. Cambridge, UK: Cambridge University Press.

Wittgenstein, Ludwig. 2001. Philosophical Investigations. Translated by GEM Anscombe. Hoboken, NJ.

\footnotetext{
${ }^{14}$ Thanks to participants at the 2012 Wittgenstein Workshop at the University of Chicago, and the participants at the "Experience, Intimacy, and Authority" at the Carlos III University in Madrid in 2012. I also thank Katie Kelley, Gregg Horowitz, Dan Morgan, Robert Pippin, and Joel Snyder for their insight and conversation.
} 